論文

\title{
大さい電極ギャップ長における合成樹脂のアーク劣化の研究
}

$$
\text { 池尻忠夫* 川本昂** }
$$

\section{Studies on Arc Deterioration of Synthetic Resin with Electrodes Having Long Gap Length}

by

\section{Tadao IKEJIRI* and Akira KAWAMOTO**}

Many studies on arc deterioration of electrical insulating materials by high voltage-low current arc have hitherto been done by using small size samples with electrodes having short gap length. In this paper, the arc resistance tests different from the previous ones were carried out by applying higher voltage and longer electrode gap length than before. Arc resistance was measured by a new arc resistance test method and the process of arc deterioration was investigated.

As the experimental method, ASTM D495 standard test method was modified a little. Electrodes were the stainless steel plate type of $5 \sim 100 \mathrm{~mm}$ in length and the applied voltage was max. $100 \mathrm{kV}$. Furthermore, arc resistance in the case of electrodes detouched from the sample surface was also investigated.

The experimental results are summarized as follows:

(1) The arc resistance of insulating materials measured with contact electrodes having long gap length showed two different tendencies depending upon the species of insulating materials, one showing a slow increase with increasing gap length from about $40 \mathrm{~mm}$ to $100 \mathrm{~mm}$, and the other a tendency of saturation at the gap length of $50 \mathrm{~mm}$ or more. Thus, the effect of electrode gap length on arc resistance was observed clearly.

(2) The arc resistance of insulating materials measured with detouched electrodes having long gap length also showed two different tendencies depending upon the species of insulating materials, one showing a slow increase with increasing gap length from about $30 \sim 40 \mathrm{~mm}$ to $100 \mathrm{~mm}$ and the other nearly constant. Thus, the separation of electrodes from the sample surface affected arc resistance remarkably and the effect of electrode gap length on arc resistance was observed in this case also.

(3) The effect of spatial configuration of sample on the arc resistance of insulating materials exists not only in comparatively small electrode gap length but also in long one. キー・ワード：大きい電極ギャップ長，耐アーク性，空間配置

\section{1 緒言}

最近, 電気機器の大容量化に伴い, それらに用いら れる絶縁物の寸法はますます大形化するとともに，特 にアークを発生する機器を対象とした場合, 充分な耐 アーク性をもつことが要求される. これら構造絶縁物 の寸法は，一般に通常の耐アーク性試験に用いられる 標準の試料に比べて大きいのが普通である.

ところで, 従来電気絶縁材料のアーク劣化について は高電圧小電流アークの場合, 小さい電極ギャップ長 のとさはかなり研究が行われているが，大きい電極ギ ヤップ長のときはほとんど行われていない.したがっ て試験法だけでなく，具体的に絶縁材料の耐アーク性 の序列が，大きい電極ギャップ長のときも不変なのか， あるいは変化を生ずるのかといらよらな基礎資料とし て利用しらるものは見られない現状で, 今日大きい電
極ギャップ長のときの絶縁設計を行ら場合資料が不足 し, 耐アーク性の評価には小さい電極ギャップ長の場 合のいままでの耐アーク性試験の結果を利用するほか はない，ゆえに，さらに高電圧の，また大きな電極ギ ヤップの長さのもとでの耐アーク性試験に期待される ところが大きいと思われる。

したがって，本稿に拈いては従来の耐アーク性試験 と異なり,さらに高い電圧を印加し，またより大きな 電極ギャップの長さのもとで耐アーク性試験を行い, 耐アーク性を測定し，またアーク劣化過程を調べた.

\section{2 実験方法ならびに試料}

実験方法としては注 （断続的にアークを発生させる方法）に準じたが，ア ークが充分試料面をはらようにスペーサを設け同一材 料で上面を执抽ている。［Fig.1 (a)] なた電極は厚

$†$ 原稿受理 昭和60年5月8日 Received May 8, 1985

* 正会 員 福井大学工学部 福井市文京, Faculty of Engineering, Fukui University, Bunkyo, Fukui

** 福井工業高等専門学校 鯖江市下司町, Fukui Technical College, Geshi-cho, Sabae 


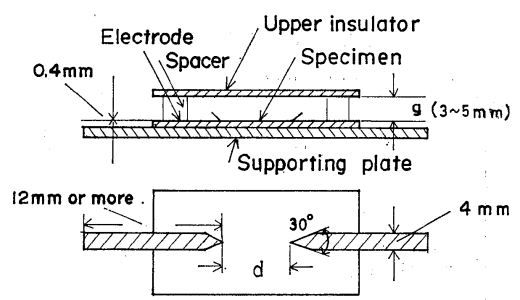

(a)

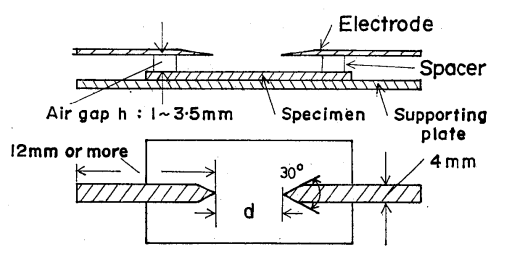

(b)

Fig. 1. Electrode assembly.

さ $0.4 \mathrm{~mm}$, 幅 $4 \mathrm{~mm}$, 長さ $12 \mathrm{~mm}$ 以上のステンレ ス鋼製平板電極で， $50 \pm 5 \mathrm{~g}$ の荷重を加えて供試面に 密着させ，かつ，その先端は鋭角にし放電の安定を期 している. 電極ギャップの長さは 5〜100 mm とし, 試料面（電極上面）と上部絶縁材料とのギャップは 3 〜 $5 \mathrm{~mm}$ とした. また電極ギャップの長さが大きく， アークが充分試料面にはらような場合には上面を和括 ら絶縁材料は取去って実験を行った. 印加電圧は最大 $100 \mathrm{kV}$ (商用周波数 $60 \mathrm{~Hz}$ ) で, 高電圧変圧器として は一次電压 $100 \mathrm{~V}$, 二次負荷電圧 $100 \mathrm{kV}$, 二次短絡 電流 0.04Aのものを用いた. な拉，電極形状，電極 ギャップの長さ, 印加電圧なぞの変化に基づくアーク 電流の変動に対しては, 試験回路で一次側回路の電流 制御抵抗を調整し，ASTM 法の場合と同一電流值に 保つよらにした. またアーク断続時間も ASTM 法の 場合と全く同じである。このような電極配置のもとで 各種の試料について耐アーク性時間（アーク抵抗）を 求めた.

さらに電極が供試面より離れて配置された場合の耐 アーク性についても調べるため Fig. 1 (b) の電極配置 のもとで実験を行った.なお，このような場合の劣化 では劣化の終結点はえられず，両電極よりの試料面劣 化部への微小アークが最後まで消隇することなく継続 発生するので普通の意味での耐アーク性時間の判定は 不可能である. したがって，ここでは劣化路が進展し 両電極先端下部近傍‡で到達し, 以後進行が停止する までの時間をもって耐アーク性時間とした.

また，いずれの実験の場合とも室温，無風状態のも

*1一般に, 最初アークは試料面上の大気中に発生するが, 試料面の 絶縁が破境されて抵抗值が小さくなるとアークは消滅し，電流は 試料面の導電層によって運ばれるようになる。このようにアーク が消滅するととはアーク劣化が完了したととを示し，ての状態を 指す。な㧍，電圧印加後アークが消滅するまでの時間を測定して 耐アーク性時間とする。
とで行った。試料としてはフェノール樹脂, エポキシ 樹脂, ポリエステル樹脂, 塩化ビニール樹脂などの各 種の合成樹脂を使用した (Table I)。なお，試料は測 定前に表面をベンゼンでふき，中性洗剤で洗浄し，さ らに水道水と蒸留水で洗浄したのち乾布で水分をらき とったものを実験に供した。

Table I. Tested materials.

\begin{tabular}{l|l}
\hline & Phenolic-paper \\
Thermosetting resin & $\begin{array}{l}\text { Epoxy-glass laminate } \\
\text { Polyester-glass laminate } \\
\text { Melamine-glass laminate }\end{array}$ \\
\hline Thermoplastic resin & Polyvinyl chloride \\
\hline
\end{tabular}

\section{3 実験結果とその考察}

\section{$3 \cdot 1$ 電極が試料面上に配置された場合の大きい電} 極ギャップ長における絶縁材料の耐アーク性

各種の絶縁材料について電極ギャップの長さを大き くした場合の耐アーク性時間（アーク抵抗）特性の測 定の結果を示すと Fig. 2 のようになる（耐 アーク性 時間はいずれも 5 〜0回の測定值の最大值, 最小值捛 よびメジアンをもって示した). 図からわかるよらに, 電極ギャップの長さの比較的小さい場合には曲線の形 状は落ら込久を有する $\mathrm{N}$ 字状曲線を示すが，さらに電 極ギャップの長さが大さくなるにつれ耐アーク性は再 び大きくなるよらになる.フェノール樹脂, 塩化ビニ 一ル樹脂の場合では電極ギャップの長さが大きくなる と，それに伴い電極ギャップ長 $100 \mathrm{~mm}$ のときまで も耐アーク性時間は増大する傾向を示すが，エポキシ ガラス積層板, ポリエステルガラス積層板, メラミン ガラス積層板の場合では，電極ギャップの長さが 50 $\mathrm{mm}$ 程度をこえた付近から飽和に達する傾向がみられ る. いずれの絶縁材料の場合とも電極ギャップ長 80 $\mathrm{mm}$ 程度以上になるとアーク放電は極めて不安定とな

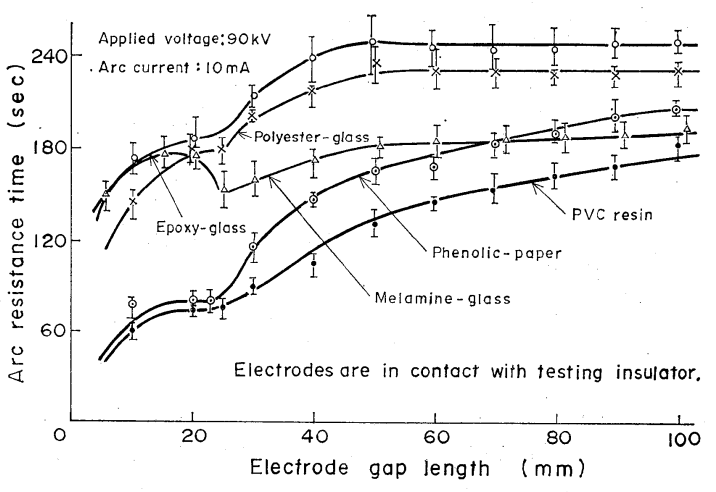

Fig. 2. Arc resistance time vs. electrode gap length in the case of electrodes touched to testing insulator. 


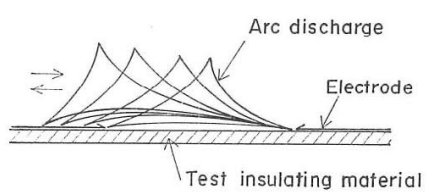

There also exists the moving of arc discharge column at other electrode.

Fig. 3. Unstable moving of arc discharge column at the electrode.

りやすく, Fig.3のよらにアークの放電柱が移動しや すく,このよらな不安定なアーク放電の生じている間 は，アーク放電路が試料面に接触しにくくアーク劣化 の進展は葟とんど認められなかった（Fig.2 の電極ギ ヤップ長 $80 \mathrm{~mm}$ 程度以上の各絶縁材料の耐アーク性 時間は不安定なアーク放電が生じていない場合の測定 結果を示したものである)。このよらなアークの放電 柱の移動の原因については現在のところ不明である.

な和，電極ギャップの長さの大きい場合の，代表的 なアーク劣化路の一例资示与と Fig. 4 のようである.

つぎにアーク劣化過程を外観的に追究するためにア 一ク劣化路に着目し，形態学的に検討した．各種の合 成樹脂について劣化路の電極軸よりのへだたりの最大 值, 劣化路の電極軸よりの偏向角の最大值などを電極 ギャップ長に対して示したものが Fig. 5 である. こ れよりアーク劣化路は樹脂の種類にもよるが電極ギャ ップ長が大きくなると一般に電極軸より離れて生成さ れるよらになることがわかる。

なお，Fig. 2 の結果から耐アーク性時間の変化は電 極ギャップの長さが大きくなるにつれ比例的に増大し てはいない.乙か子各種の絶緑材料によって耐アーク

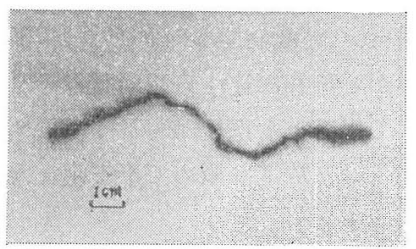

Phenolic - paper Electrode gap length: $100 \mathrm{~mm}$ Applied voltage: $90 \mathrm{kV}$

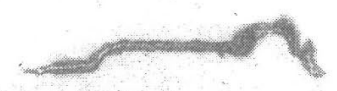

Polyester-glass

Electrode gap length: $100 \mathrm{~mm}$ Applied voltage : $90 \mathrm{kV}$

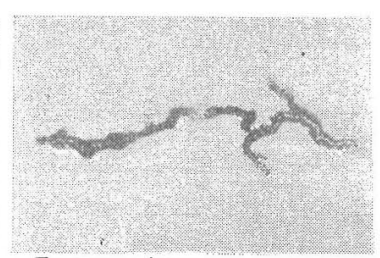
Electrode gap length: $100 \mathrm{~mm}$ Applied voltage : $90 \mathrm{kV}$

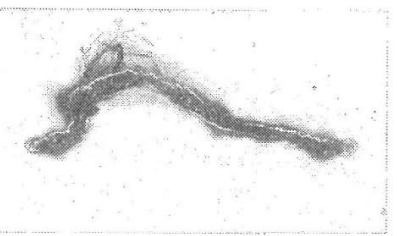

PVC resin

Electrode gap length: $100 \mathrm{~mm}$ Applied voltage : $90 \mathrm{kV}$
Epoxy-glass

Fig. 4. Appearance of typical arc deterioration path in synthetic resin.

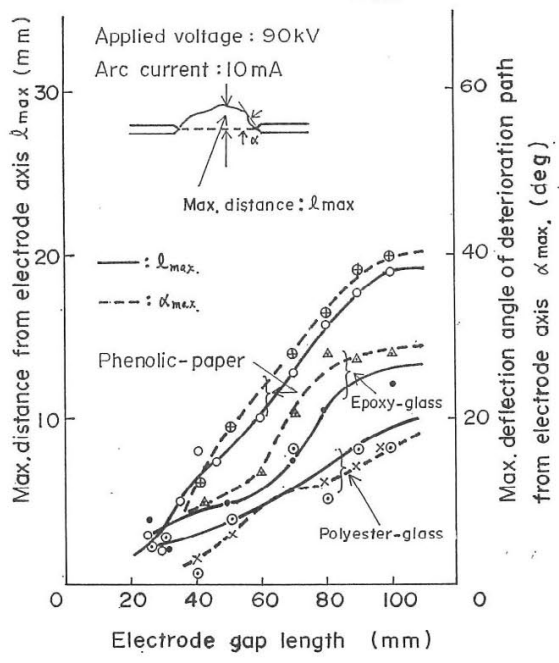

Fig. 5. Max. distance $l_{\max }$ or max. deflection angle $\alpha_{\max }$ vs. electrode gap length.

性時間の恋化の傾向がいくらか異なり，一般に小さい 電極ギャップ長の場合と大きい電極ギャップ長の場合 では絶縁材料の耐アーク性の序列が变化し，それの小 さい電極ギャップ長の場合と大きい電極ギャップ長の 場合の対応性の点に問題があり, 電極ギャップ長の効 果が認められる.

$3 \cdot 2$ 電極が試料面より離れて配置された場合の, 大きい電極ギャップ長における絶縁材料の耐 アーク性

一般に ASTM D495 標準試験法のように電極が試 料面上に配置される場合には，アーク劣化時末期電極 先端近傍に火点（白熱状炭素と考えられる）を生じ,

これの対向極への進行により炭化路が形成 され，劣化が完了する，したがって，劣 化時間，すなわら耐アーク性時間の判定は 容易である.しかしながら，電極が試料面 より離れて配置された場合では，両電極よ り試料面上の劣化部に連なる微小アークが 試料劣化後も依然として存在し，アーク劣 化時間の判定は困離である.な拉，この場 合に拈いてす電極ギャップの長さが比較的 大きいときは，アーク劣化時末期, 試料面 上で微小アーク放電路先端に火点が生成さ れ, 対向極方向に進行し, 炭化路を形成し, 試料は劣化するが, 火点の進行の状態はや や複雑で方る。すなわら刘向極に向い火点 が進行したのち, さらに新しい火点が発生 し, これらは点発生電極方向に引返すよ らな動きを示す。としてほ添電極下部 (1 〜2 mm 電極後方にまで進行することが多 い）まで到達して静止する。この状態では 


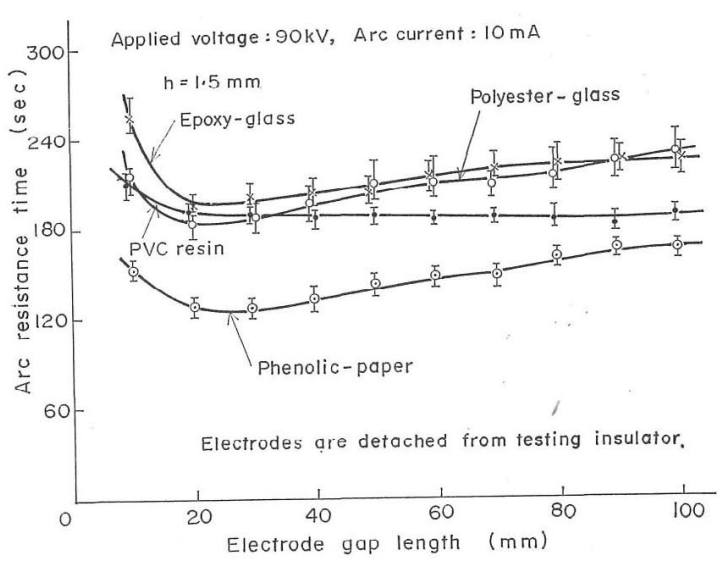

Fig. 6. Arc resistance time vs. electrode gap length in the case of electrodes detouched from testing insulator.

両電極下間劣化部は一本の細長い劣化路を示し，アー ク劣化の進行の特徴を表している. 電極ギャップの長 さが大きい場合劣化路が大きく屈曲するのは，電極が 試料面上に配置されたとをと同様である。ここではこ のような劣化路の形成時間をアーク劣化時間，すなお ち耐アーク性時間とした。

いま各種の樹脂の試料について雨電極と試料面のエ アギャップが $1.5 \mathrm{~mm}$ の場合, 電極ギャップの長さを 大きくしたときのアーク劣化時間特性の測定結果を示 すと Fig.6 の上らになる。図からわかるよらに，曲 線の形状は谷を有するV字状曲線を示し，耐アーク性 時間は極めて電極ギャッ長が小さい場合より乞れが大 きくなるにつれ減少するが，さらに電極ギャップ長が 大さくなるとともに增大するよらになる。しかも電極 ギャップ長が $100 \mathrm{~mm}$ に至るまでるゆるやかに上昇し つづけている。ただし，電極ギャップ長 100 $\mathrm{mm}$ に至るおでほとえど変化のみられない昜合 も存在する。な和このよらな耐アーク性時間 の変化の傾向心各種の樹脂に上ってやや異なる ことが知られ，谷に拈ける電極ギャップの長さ も文献2)の場合と同じく,フェノール樹脂，塩 化ビニール樹脂, エポキシガラス積層板, ポリ エステルガラス積層板などの場合ともいくらか 相違している。ここでアーク放電路の外観を示 すと Fig. 7 のようで電極ギャップの長さ 20〜 $23 \mathrm{~mm}$ 程度までの場合, 一般には(a)図のよう に放電路は上方に湾曲しやすいが，電極ギャッ プの長さ 23 30 mm 程度以上では(b)図に示さ れる上らになり，しかも上下左右に移動しやす い。また，この後者の場合の炭化焼損路は，両 電極と試料面とのエアギャップにもよるが，前 述のよらに一般には自電極上り試料面上の劣化 炤和 61 年 4 月

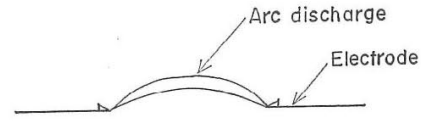

(a) Arc discharge in the comparatively small electrode gap length.

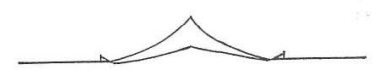

(b) Arc discharge in the comporatively large electrode gap length.

Fig. 7. Variation of the appearance of arc discharge with the change of electrode gap length.

部（アークの陽光性の接触により生ずる）を連ねる微 小アークの先端に発生する火点の対向極への進行によ り生ずるため, 細い暁損路となり，前者の場合の獟損 部が表面に沿い広く拡がる劣化の形態(この場合には 放電路以試料面にはい難〉, 火点の生成は2られない。 そして附アーク性時間も比較的大きくなる。）とは明 らかに相違している (Fig. 8).

以上よりアーク劣化時間特性に谷を生じた理由とし ては, 文献2)の電極ギャップ長 $50 \mathrm{~mm}$ 以下の場合と 同じく, アーク放電路の試料面への接触の模様が大き く变化していることが考光られる。すなわも，比較的 電極ギャップ長が小さい場合，アーク放電路は試料面 より離れやすく,ささらに電極ギャップの長さが大きく なるとアーク放電路は充分試料面に触れるようになり， また一層電極ギャップの長さが大きくなってもアーク 放電路は比較的よく試料面に接触することによるため と思われる。

さて Fig. 6 からわかるよらにアーク劣化時間の変

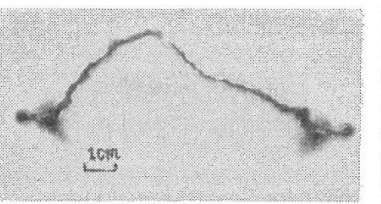

Phenolic - paper

Electrode gap length: $100 \mathrm{~mm}$

Applied voltage : $90 \mathrm{kV}$

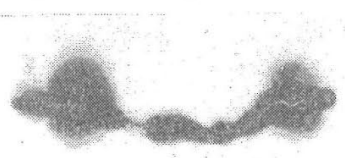

Polyester - glass

Electrode gap length: $100 \mathrm{~mm}$ Applied voltage : $90 \mathrm{kV}$ case of electrodes detouched from testing insulator. 
化は電極ギャップの長さが大きくなるにつれ比例的に 増大してしない: しか子各種の絶縁材料によってアー ク劣化時間の変化傾向がいくらか異なり, 一般に小さ い電極ギャップ長の場合と大きい電極ギャップ長の場 合では絶縁材料の耐アーク性の序列が変化し，それの 小さい電極ギャップ長の場合と大きい電極ギャップ長 の場合の対応性の点に問題があり， $3 \cdot 1$ 節のときと同 様電極ギャップ長の効果が認められる.

\section{$3 \cdot 3$ 大きい電極ギャップ長における絶縁材料の耐 アーク性に及ぼす試料の空間配置の効果}

従来電気絶縁材料の耐アーク性に及ぼす試料の空間 配置の効果の 研究は，電極ギャップ長が 40〜50 mm 程度までの場合は既に報告されているが，さらに電極 ギャップ長が大きくなり，100 mm 程度となるような 場合についてはほとんぞ発表されては特らず，したが って具体的に基礎資料として利用しらるものはみられ ない現状である.ゆ元に種々の空間配置での，大きい 電極ギャップ長のときの/絶縁設計を行ら場合資料が 不足し, 耐アーク性の評価には電極ギャップ長 $40 \mathrm{~mm}$ 程度までのいままでの耐アーク性試験の結果を利用す るほかはなく，さらに高電圧の，大きい電極ギャ ップ長のもとでの，空間配置を種々変えた場合の耐ア 一ク性試験に期待されるところが大さいと考えられる。 さて実験方法としては $\mathbf{3} \cdot \mathbf{1}$ ならびに $\mathbf{3} \cdot \mathbf{2}$ 節の場合 と同様ほぼ ASTM D495 標準試験法に準じたが，電 極な供試面に密着させ，また電極ギャップの長さは最 大 $100 \mathrm{~mm}$ とした. な拉, 印加電圧は $90 \mathrm{kV}$ (商用周 波数 $60 \mathrm{~Hz})$ で，アーク電流は ASTM 法の場合と同 じく $10 \mathrm{~mA}$ となるよらにした。またアーク断続時間 も ASTM 法の場合と全く同じである.

各種の絶縁材料について電極 ギャップの長さが 80 $\mathrm{mm}$ の場合の試料の空間配置の耐アーク性時間特性に 及ぼす効果を示すと Fig. 9 のようになる.ここで試 料の空間配置としては，水平なる位置より，電極軸と 垂直なる方向（試料面上）を軸として一回転する場合 と電極軸の回りに一回転する場合の二つについて考え， 試料面の水平面よりの各傾斜角度の場合について耐ア ーク性時間を求めた。図からわかるように曲線の形状 はいずれの空間配置の場合とも最小值を有する $\mathrm{V}$ 字状 曲線を示し，乙かもこの最小值は電極ギャップ長が比 較的小さいときと同様傾斜角度が $180^{\circ}$ のときに認め られる。すなわら裏返しの配置に执いて生ずるのが知 られる。

ところで, 絶縁材料の種類によってこれらの曲線が 互いに交差する場合がみられ，試料の傾斜角度によっ て耐アーク性の序列が変化するのが認められる.すな わち電極ギャップの長さが $80 \mathrm{~mm}$ 程度と大きいとき も, 電極ギャップの長さが $6 \sim 50 \mathrm{~mm}$ 程度と比較的小

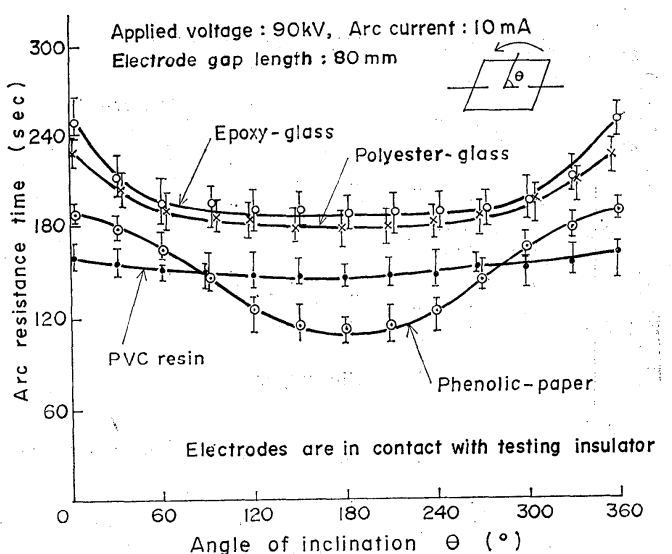

(a)

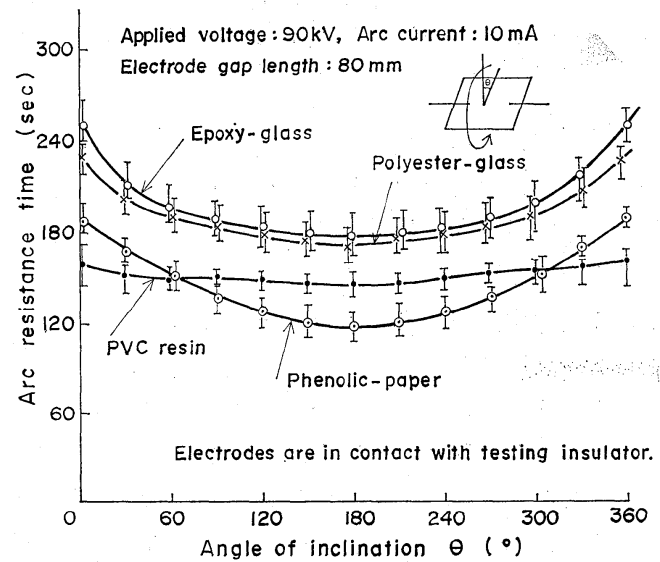

(b)

Fig. 9. Arc resistance time vs. angle of inclination of specimen.

さいときと同様，耐アーク性に及ぼす試料の空間配置 の効果が存在することがわかる。

\section{4 結 : 言}

以上，大きい電極ギャップ長のもとでのアーク劣化 について実験的に調べたが，要約すると次のようであ る.

（1）電極が試料面上に配置された場合の，大きい電 極ギャップ長に和ける絶縁材料の耐アーク性は，絶縁 材料の種類により電極ギャップ長 $40 \mathrm{~mm}$ 程度より $100 \mathrm{~mm}$ に至るまでゆるやかに増大する傾向を示すと きと電極ギャップ長 $50 \mathrm{~mm}$ をこえる付近から飽和す る傾向を示すときなどがある、また，ここで小さい電 極ギャップ長の場合と大きい電極ギャップ長の場合で は絶縁材料の耐アーク性の序列に和いて，その対応性 の点に問題があり，耐アーク性に及ぼす電極ギャップ 長の効果が認められる.

な和アーク劣化路は電極ギャップ長が大きくなると 一般に電極軸より離れて生成されるようになる。

（2）電極が試料面より離れて配置された場合の，大 
きい電極ギャップ長における絶縁材料の耐アーク性は, 絶縁材料の種類により電極ギャップ長 30〜 $40 \mathrm{~mm}$ 程 度により $100 \mathrm{~mm}$ に至るまでゆるやが增大する傾向 を示すときとほとんど変化を示さないとさなどがある. すなわち, 電極が試料面より離れて配置された場合は, 大きい電極ギャップ長に扮いても耐アーク性の増大が みられにくいときがあり，電極の試料面よりの離隔は 大きい電極ギャップ長のもとでの耐アーク性に重大な 影響を与える。なお，この場合も耐アーク性に及汸す 電極ギャップ長の効果が存在する.
（3）大きい電極ギャップ長に括ける絶縁材料の耐了 ーク性に及ぼす試料の空間配置の効果は電極ギャップ 長が比較的小さいときと同様存在する.

\section{参 考 文 献}

1）池㞔忠夫, 電気学会論文集, A-92，351 (1972).

2）池尻忠夫，材料， 27, 384 (1978).

3) H. Warren, J.I.E.E., 87, 528 (1940).

4）池尻忠夫，材料，25，193 (1976). 